José Barberán ${ }^{1}$

Rubén Restrepo ${ }^{2}$

Pablo Cardinal-Fernández ${ }^{3}$

\section{Community-acquired pneumonia: similarities and differences between European and American guidelines - A narrative review -}

\author{
${ }^{1}$ Internal Medicine Department, HM Monteprincipe University Hospital. Madrid, Spain. \\ San Pablo CEU University. Madrid, Spain. \\ ${ }^{2}$ The University of Texas Health Science Center at San Antonio. Texas, USA \\ ${ }^{3}$ Intensive Care Unit. HM Sanchinarro University Hospital. Madrid, Spain
}

Article history

Received: 1 October 2020; Revision Requested: 13 October 2020; Revision Received: 15 October 2020; Accepted: 19 0ctober 2020; Published: 9 December 2020

\begin{abstract}
Community-acquired pneumonia (CAP) is severe disease. Early prescription of an adequate treatment has a positive impact in the CAP outcome. Despite the evidence of existing relevant differences between CAP across geographical areas, general guidelines can be designed to be applied everywhere. Eight years have passed between the publication of the European (EG) and American (AG) CAP guidelines, thus the aim of this narrative review is to compare both guidelines and summarize their recommendations. The main similarity between both guidelines is the antibiotics recommendation with the exception that $A G$ mention new antimicrobials that were not available at the time of $E G$ publication. Both guidelines recommend against routinely adding steroids as an adjuvant treatment. Finally, both guidelines acknowledge that the decision to hospitalize a patient is clinical and should be complemented with an objective tool for risk assessment. EG recommend the CRB-65 while AG recommend the Pneumonia Severity Index (PSI). EG and AG share a similar core of recommendations and only differ in minor issues such as new antibiotics. Likewise, both guidelines recommend against the routine prescription of steroids as an adjuvant therapy.
\end{abstract}

Key words: Community-Acquired Pneumonia; respiratory infections; European guidelines; American guidelines

\section{Neumonía aguda comunitaria: similitudes y diferencias entre las guías Europeas y Americanas. Revisión narrativa}

La neumonía adquirida en la comunidad (NAC) es una enfermedad grave. La prescripción temprana de un tratamiento adecuado ha demostrado mejorar el pronóstico de esta enfermedad. A pesar de que existen evidentes diferencias entre las NAC de acuerdo al área geográfica en la cual es diagnosticada, es posible realizar recomendaciones generales capaces de ser aplicadas en todo el mundo. Han pasado ocho años entre la publicación de las guias Europeas (GE) y Americanas (GA) de la NAC por lo cual el objetivo de la presente revisión narrativa es comparar ambas guias y resumir sus recomendaciones. La principal similitud entre ambas guias son las recomendaciones en los planes de antibióticos, con la diferencia que las GA mencionan a los nuevos antimicrobianos que no estaban disponible al momento de la publicación de GE. Ambas pautas recomiendan contra de la prescripción rutinaria de esteroides como tratamiento adyuvante. Finalmente, ambas guias reconocen que la decisión hospitalizar a un paciente es clínica, aunque debe complementarse con una herramienta objetiva para la evaluación de riesgos. Las GE recomiendan a la escala CRB-65 mientras que las GA al indice de severidad de la neumonía (PSI). En suma, ambas guías comparten la mayoría de las recomendaciones solo difiriendo en aspectos menores como los nuevos antibióticos. Ambas guias recomiendan en contra de la prescripción rutinaria de esteroides como terapia adyuvante.

PALABRAS CLAVE: Neumonía aguda comunitaria, infección respiratorias, guías Europeas de neumonía aguda comunitarias, guías Americanas de neumonia aguda comunitaria. 


\section{BACKGROUND}

Community-acquired pneumonia (CAP) is a serious health threat due to its high rate of complications and mortality [1-5]. Clinical practice guidelines (CPG) emerged to improve quality of care and standardization of patients' management [6]. Ideally, these documents should cover all aspects of a disease and support their recommendations with high quality evidence allowing physicians to make the best decision. For example, early prescription of an appropriate antimicrobial treatment can positively impact the CAP outcome [7]. Although, it is evident that exists relevant differences between CAP microbiology across geographical areas $[8,9]$; it is also true that it is possible to identify general rules to be applied everywhere.

Continental and well accepted scientific societies regularly publish CAP CPG, in Europe the newest were published in 2011 [10] and in the United States during 2019 [11]. The aim of this narrative review is to compare both guidelines and summarize their recommendations.

\section{SCOPE AND DEFINITIONS}

The scope of European Guidelines (EG) is the management of adult patients with lower respiratory tract infections (LRTI). LRTI is defined as an acute illness (present for 21 days or less), usually with a cough, lower respiratory tract symptoms (sputum production, dyspnea, wheeze or chest discomfort/pain) and without an alternative explanation. In other words, LRTI is considered as an umbrella that can include patients with specific (for example acute bronchitis, influenza, exacerbation of chronic obstructive pulmonary disease [ECOPD], acute exacerbation of bronchiectasis [AEBX] and CAP) or non-specific respiratory entities. European guidelines provides two levels of certainty for the CAP definition, suspect ("an acute illness with cough and at least one of new focal chest signs, fever $>4$ days or dyspnoea/tachypnea, and without other obvious cause") or definitive (the previous definition but "supported by chest radiograph findings of lung shadowing that is likely to be new"). Conversely, the American guidelines (AG) are more restrictive and focus their recommendations only in adult and immunocompetent patients with radiologically confirmed CAP from United States, who have not completed foreign travels especially to regions with emerging respiratory pathogens [11].

Diagnosing a pneumonia is usually more complex than it appears, especially in overcrowded emergency departments. Traditional approaches include three basic categories: community, hospital and health-care associated pneumonia. The first and second term have been used for a long time; the third was mainly based on early results published by Kollef et al [12] that were not reproduced $[13,14]$. Thus, both guidelines recommend abandoning this term as it is confusing and is not clear that this type of patients are associated with an increased risk of resistant microorganism.

\section{CAP DIAGNOSIS AND MICROORGANISM IDENTIFICATION}

In non-hospitalized patients suspected of having CAP (presence of at least one of the following clinical findings: new focal chest signs, dyspnea, tachypnea, pulse rate $>100$ or fever $>4$ days), EG propose to perform a serum-level of $\mathrm{C}$-reactive protein (CRP). If the CPR level is lower than $20 \mathrm{mg} / \mathrm{L}$ at presentation and the symptoms have been present for more than 24 hours, the probability of having CAP is low. On the other hand, if the CPR level is higher than $100 \mathrm{mg} / \mathrm{L}$, the probability is high. In the case of persisting doubt after CPR testing, a chest X-ray should be considered to confirm or reject the diagnosis.

Regarding the etiology, it was demonstrated that the proportion of causative microorganism isolated from CAP patients is $38 \%$, despite the complexity or number of diagnose techniques applied. In most of the cases they are viruses (23\%) followed by bacteria $(11 \%)$, bacteria and viruses $(3 \%)$, and fungi or mycobacteria (1\%) [1].

Concerning tests for microorganism identification, both guidelines agree that they are not indicated in the out-patient setting. However, in those that require hospitalization the recommendations are the following (table 1):

- Gram stain and culture of respiratory secretions. The EG recommend obtaining sputum for Gram stain and culture when a purulent sample can be obtained and processed in timely manner. On the other hand, AG recommend these studies in the following situations: (a) in severe CAP (especially if they are intubated), (b) when an empirically treatment for methicillin-resistant Staphylococcus aureus (MRSA) or Pseudomonas aeruginosa will be performed, (c) when the patient has been infected with MRSA and/or P. aeruginosa (especially those with prior respiratory tract infection) or (d) in patients who were hospitalized and received parenteral antibiotics during the last 90 days.

- Blood culture. The EG recommend obtaining two set of blood culture in all patients that require hospitalization. Meanwhile, AG recommend only culture the blood in the four previously described scenarios (vide supra).

- Streptococcus pneumoniae urinary antigen. Traditional assays based on immunochromatographic membrane have a sensitivity and specificity of $75 \%$ and $95 \%$, respectively $[15,16]$. However, new luminex-technology-based multiplex urinary antigen tests have achieved a sensitivity of $97-98 \%$ and a specificity of 100\% for proven pneumococcal CAP [17]. The EG recommend detecting this antigen only in hospitalized patients and $A G$ in the subgroup of hospitalized patients with severe CAP.

- Legionella pneumophila urinary antigen. This test has a sensitivity of $75 \%$ to $80 \%$ and a specificity of nearly $100 \%[18,19]$. Recommendations for this test are similar to previous with the exception that is also recommended when there is an epidemiologic risk factor (e.g. Legionella outbreak or recent travel to a risky geographical region). 


\begin{tabular}{|c|c|c|}
\hline $\begin{array}{l}\text { Compariso } \\
\text { for hospita }\end{array}$ & $\begin{array}{l}\text { etween microbiological analysis recommenc } \\
\text { ed patients with a community acquired pne }\end{array}$ & $\begin{array}{l}\text { ations in European and American guidelines } \\
\text { monia }\end{array}$ \\
\hline & European Guidelines - 2011 & American Guidelines - 2019 \\
\hline Blood cultures & All patients with CAP who require hospitalization. & $\begin{array}{l}\text { Not routinely recommended. Recommended when CAP } \\
\text { is classified as severe;is empirically treated for MRSA or } \\
\text { P. aeruginosa; were previously infected with MRSA or P. } \\
\text { aeruginosa, especially those with prior respiratory tract } \\
\text { infection; were hospitalized and received parenteral antibiotics, } \\
\text { whether during the hospitalization event or not, in the last } 90 \\
\text { days. }\end{array}$ \\
\hline Bronchoalveolar lavage & The preferred technique in non-resolving pneumonia. & Not mentioned. \\
\hline $\begin{array}{l}\text { Bronchoscopic sampling of the lower } \\
\text { respiratory tract }\end{array}$ & When gas exchange status allows. & Not mentioned. \\
\hline Purulent sputum examination & $\begin{array}{l}\text { Gram strain: should be performed when can be obtained and } \\
\text { processed in a timely manner. Culture: should be considered } \\
\text { for confirmation of the species identification and antibiotic } \\
\text { susceptibility testing. }\end{array}$ & $\begin{array}{l}\text { Pretreatment Gram stain and culture is recommended in patients } \\
\text { who: are classified as severe especially if they are intubated; } \\
\text { are being empirically treated for MRSA or P. aeruginosa; were } \\
\text { previously infected with MRSA or P. aeruginosa, especially } \\
\text { those with prior respiratory tract infection; were hospitalized } \\
\text { and received parenteral antibiotics, whether during the } \\
\text { hospitalization event or not, in the last } 90 \text { days. }\end{array}$ \\
\hline S. pneumoniae & $\begin{array}{l}\text { Urinay antigen should be performed in patients admitted to the } \\
\text { hospital for reasons of illness severity,whenever a pleural fluid } \\
\text { sample is obtained in the setting of a parapneumonic effusion } \\
\text { and quantitative molecular tests in sputum or culture blood } \\
\text { may be valuable in CAP patients in whom antibiotic therapy has } \\
\text { been initiated and may be a useful tool for severity assessment. }\end{array}$ & $\begin{array}{l}\text { Not routinely testing urine for antigen, recommended in severe } \\
\text { CAP. }\end{array}$ \\
\hline L. pneumophila & $\begin{array}{l}\text { Urinary detection should be performed in patients admitted } \\
\text { to the hospital for reasons of severity or when is clinically or } \\
\text { epidemiologically suspected. }\end{array}$ & $\begin{array}{l}\text { Not routinely testing urine antigen; recommended when } \\
\text { epidemiological factors (eg. Legionella outbreak or recent travel) } \\
\text { or severe CAP is present. }\end{array}$ \\
\hline $\begin{array}{l}\text { M. pneumoniae, C. pneumoniae and } \\
\text { Legionella serology }\end{array}$ & Mainly for epidemiological studies. & Not mentioned. \\
\hline $\begin{array}{l}\text { Influenza and respiratory syncytial } \\
\text { virus }\end{array}$ & Molecular test should be considered during the winter season. & $\begin{array}{l}\text { Testing influenza with a molecular assay (eg. PCR) when it is } \\
\text { circulating in the community. }\end{array}$ \\
\hline Thoracentesis & $\begin{array}{l}\text { Hospitalized patients with CAP when a significant (as judged by } \\
\text { the admitting physician) pleural effusion is present. }\end{array}$ & Not mentioned. \\
\hline Transthoracic needle aspiration & $\begin{array}{l}\text { Can be considered ONLY on an individual basis for some } \\
\text { severely ill patients, with a focal infiltrate, in whom less invasive } \\
\text { measures have been non-diagnostic. }\end{array}$ & Not mentioned. \\
\hline
\end{tabular}

- Influenza virus. Traditional rapid influenza diagnostic tests have a sensitivity of $60 \%$ and a specificity of $98 \%$ [20]. Newer tests, based on rapid nucleic acid amplification, have increased their sensitivity to more than 90\% maintaining the high specificity [21]. Both guidelines recommend detecting influenza and respiratory virus guided by epidemiological factors.

- Mycoplasma pneumonia and Chlamydia pneumoniae (only mentioned in EG). Only use these tests when a high clinical suspicion of atypical agent exists and always associated with PCR techniques.
- Invasive techniques (only mentioned in EG). Thoracocentensis should be performed in hospitalized patients with CAP when a significant pleural effusion is present. Bronchoscopic protected specimen brush, bronchoalveolar lavage and quantitative endotracheal aspirate should be the preferred technique in non-resolving pneumonia. Transthoracic needle aspiration can be considered only in exceptional circumstances of severely ill patients, with focal infiltrates in whom less invasive techniques have been non-diagnostic. 


\section{Table 2 Comparison between empirical antibiotic recommendation in European and American guidelines for hospitalized patients with a community acquired pneumonia}

\begin{tabular}{|c|c|c|}
\hline & European Guidelines - 2011 & American Guidelines - 2019 \\
\hline $\begin{array}{l}\text { Non-severe CAP that require } \\
\text { hospitalization without risk factors } \\
\text { for P. aeruginosa or MRSA }\end{array}$ & $\begin{array}{l}\text { (a) Combination therapy } \\
\text { - Beta-lactam (penicillin } \mathrm{G} \text {, aminopenicillin or aminopenicillin/ } \\
\text { beta-lactamase inhibitor or ceftriaxone or cefotaxime) } \\
\text { plus } \\
\text { - Macrolide } \\
\text { (b) Monotherapy } \\
\text { - Non-antipseudomonal cephalosporin or respiratory } \\
\text { fluoroquinolone (levofloxacin or moxifloxacin) or ertapenem } \\
\text { (patients at risk of gram-negative enteric bacterium, } \\
\text { particularly strains with extended-spectrum beta-lactamase, } \\
\text { but without risk [or after exclusion] of } P \text {. aeruginosa) }\end{array}$ & $\begin{array}{l}\text { (a) Combination therapy } \\
\text { - Beta-lactam (ampicillin/sulbactam } 1.5-3 \mathrm{~g} \text { every } 6 \mathrm{~h}, \\
\text { cefotaxime } 1-2 \mathrm{~g} \text { every } 8 \mathrm{~h} \text {, ceftriaxone } 1-2 \mathrm{~g} \text { daily or } \\
\text { ceftaroline } 600 \mathrm{mg} \text { every } 12 \mathrm{~h} \\
\text { plus } \\
\text { - Macrolide (azithromycin } 500 \mathrm{mg} \text { daily or clarithromycin } \\
500 \mathrm{mg} \text { every } 12 \mathrm{~h} \text { ) or doxycycline ( } 100 \mathrm{mg} \text { every } 12 \mathrm{~h} \text { ) } \\
\text { (b) Monotherapy } \\
\text { - Respiratory fluoroquinolone (levofloxacin } 750 \mathrm{mg} \text { daily or } \\
\text { moxifloxacin } 400 \mathrm{mg} \text { daily) } \\
\text { a- Only in case of contraindications to both macrolides and } \\
\text { fluoroquinoloes }\end{array}$ \\
\hline $\begin{array}{l}\text { Severe CAP that require } \\
\text { hospitalization without risk factor } \\
\text { for P. aeruginosa or MRSA }\end{array}$ & $\begin{array}{l}\text { (a) Combination therapy } \\
\text { - Non-antipseudomonal cephalosporins III } \\
\text { plus } \\
\text { - Macrolide } \\
\text { (b) Monotherapy } \\
\text { - Respiratory fluoroquinolone + non-antipseudomonal } \\
\text { cephalosporins III }\end{array}$ & $\begin{array}{l}\text { (a) Combination therapy } \\
\text { - Beta-lactam (ampicillin/sulbactam 1.5-3g every } 6 \mathrm{~h}, \\
\text { cefotaxime } 1-2 \mathrm{~g} \text { every } 8 \mathrm{~h} \text {, ceftriaxone } 1-2 \mathrm{~g} \text { daily or } \\
\text { ceftaroline } 600 \mathrm{mg} \text { every } 12 \mathrm{~h} \\
\text { plus } \\
\text { - Macrolide (azithromycin } 500 \mathrm{mg} \text { daily or clarithromycin } \\
500 \mathrm{mg} \text { every } 12 \mathrm{~h} \text { ) } \\
\text { or } \\
\text { - Respiratory fluoroquinolone (levofloxacin } 750 \mathrm{mg} \text { daily or } \\
\text { moxifloxacin } 400 \mathrm{mg} \text { daily) }\end{array}$ \\
\hline $\begin{array}{l}\text { Severe CAP that require } \\
\text { hospitalization with risk factor for } \\
\text { P. aeruginosa }\end{array}$ & $\begin{array}{l}\text { (a) Combination therapy } \\
\text { - Antipseudomonal cephalosporin or acylureidopenicillin/ } \\
\text { beta-lactamase inhibitor or carbapenem } \\
\text { plus } \\
\text { - Ciprofloxacin or macrolide + aminoglycoside (gentamicin, } \\
\text { tobramycin or amikacin) } \\
\text { a- Ceftazidime has to be combined with penicillin G for } \\
\text { coverage of S. pneumoniae. } \\
\text { b- Meropenem preferred, up to } 6 \mathrm{~g} \text { possible, } 3-2 \text { in 3-h } \\
\text { infusion } \\
\text { c- Levofloxacin } 750 \mathrm{mg} / 24 \mathrm{~h} \text { or } 500 \mathrm{mg} \text { twice daily is } \\
\text { an alternative and also covers Gram-positive bacteria if } \\
\text { treatment is empirical }\end{array}$ & $\begin{array}{l}\text { (a) Monotherapy } \\
\text { - Antipseudomonal cephalosporin (cefepime } 2 \mathrm{~g} \text { every } 8 \mathrm{~h} \\
\text { or ceftazidime } 2 \mathrm{~g} \text { every } 6 \mathrm{~h} \text { ) or acylureidopenicillin/beta- } \\
\text { lactamase inhibitor (piperacillin/tazobactam } 4.5 \mathrm{~g} \text { every } 6 \mathrm{~h} \text { ), } \\
\text { or carbapenem (imipenem } 500 \mathrm{mg} \text { every } 6 \mathrm{~h} \text { or meropenem } 1 \mathrm{~g} \\
\text { every } 6 \mathrm{~h} \text { ) or aztreonam ( } 2 \mathrm{~g} \text { every } 8 \mathrm{~h} \text { ) }\end{array}$ \\
\hline $\begin{array}{l}\text { CAP that require hospitalization } \\
\text { with risk factor for MRSA }\end{array}$ & $\begin{array}{l}\text { (a) Combination therapy } \\
\text { - Teicoplanin } \pm \text { rifampin } \\
\text { (b) Monotherapy } \\
\text { - Vancomycin, linezolid or clindamycin (if susceptible) }\end{array}$ & $\begin{array}{l}\text { (a) Monotherapy } \\
\text { - Vancomycin (15mg/kg every } 12 \mathrm{~h} \text { ) or linezolid (600mg every } \\
12 \mathrm{~h})\end{array}$ \\
\hline
\end{tabular}

\section{DETERMINE WHERE THE PATIENT SHOULD BE TREATED}

Deciding where the patient should be treated requires answering two questions: should the patient be admitted to the hospital? and then, should the patient be considered for intensive level of monitoring and treatment (e.g. intensive care unit [ICU], step-down or telemetry unit)? Every physician should always be aware that delay in ICU admission is an in- dependent predictor of hospital mortality and longer length of stay [22,23]. Both guidelines acknowledge that the decision to hospitalize a patient is clinical. However, it should be complemented with objective tools for risk assessment. The EG recommend the CRB-65 while the AG recommend the Pneumonia Severity Index (PSI). Indeed, other factors exist in addition to clinical severity that should be considered at the moment of determining the need for hospital admission (e.g. inability to maintain oral intake, severe comorbid illness, impaired functions status, etc.) $[7,24,25]$. The $E G$ recognized that biomarkers 
(e.g. CRP or PCT) have a significant potential to improve assessment of severity, but have not been sufficiently evaluated to influence the hospitalization decision.

Regarding ICU admission, EG recommends admitting patients with acute respiratory failure, sepsis or septic shock, radiographic extension of infiltrate or severely decompensated comorbidities. The AG maintain the IDSA-2007 [26] recommendation for ICU admission but also mention that SMART-COP (a score for identifying patients who need vasopressor support and/or mechanical ventilation) [27] or SCAP (score for predicting the risk of adverse outcomes) [28] score could be applied.

\section{ANTIMICROBIAL THERAPY}

In most of the cases, antimicrobial therapy should be empiric and consider agents against major micro-organisms that cause CAP as well as the patient's features (e.g. presence of specific risk factor, allergies, intolerances, etc.). Regarding the micro-organisms, several observational data suggest that inpatient and outpatients CAP are caused by the same pathogens, except for Legionella and Gram-negative bacilli which are rarely documented in outpatient setting [11]. As bacterial pathogen often coexists with viruses and currently there is not a test accurate or fast enough to determine that the CAP is solely caused by a virus, AG recommend always empirically cover bacterial microorganism.

Comparison against antibacterial recommendation in $\mathrm{EG}$ versus AG can be appreciated in table 2. In addition, it is important to highlight that guidelines recommend initiating antimicrobial therapy as early as possible, within the first hour if the patient is in septic shock.

Antibacterial therapy. Although recommended antibacterial therapy is very similar in both guidelines, there are two main differences:

1. The AG recommend a list of antibiotics with a specific dose, meanwhile the EG limited their recommendation to the type of medication. In both cases, a list of possible antibiotics without any preference are reported. In 2017, the U.S. Healthcare Infections Control Practices Advisory Committee recommend that "when multiple therapeutics options are available, a hierarchy of antibiotics treatment recommendations should be provided with "first choice" options being those with adequate therapeutic efficacy, the lowest risk of facilitations antimicrobial resistance and the lowest risk of $C$. difficile..."[29]. The wide number, not hierarchical organized, options of antibiotics suggested by both guidelines have raised some concerns because they may not be in line with the previous statement [30]. Unfortunately, this problem seems difficult to be resolved in a short period of time because it is aroused by the fact that randomized clinical trials (RCTs) usually compare only two interventions, and a factorial RCT with all options is not feasible. Overall, almost all interventions are associated with high effectiveness for hard outcomes like mortality, thus conclusion about which is the best interventions should be drawn from weaker events like cure rate or frequency of side effects [31].
2. AG included ceftaroline as a beta-lactam to be combined with a macrolide (or respiratory fluoroquinolone in cases of severe (AP). At the time of EG publication, ceftaroline was not available. Ceftaroline is a fifth generation cephalosporin with a spectrum of activity similar to ceftriaxone but with an increased coverage over gram positive, particularly S. pneumoniae and S. aureus (MSSA and MRSA) [32]. Unfortunately, the evidence for recommending it, in severe patients (Fine $\mathrm{V}$ ) or as a rescue therapy, is scarce as all RCTs that tested ceftaroline excluded these subgroup of patients [33-35]. Likewise, the AG recommend prescribing vancomycin or linezolid in case of risk factors for MRSA. A recommendation that is not well supported as ceftaroline has a good activity against MRSA as the benefit of this combination has not been demonstrated.

Although both guidelines consider the association of a beta-lactam with a macrolide or a respiratory fluoroquinolone at the same level for severe CAP without risk factors for MRSA and $P$. aeruginosa, the AG mentioned two meta-analysis based on observational studies that reported a benefit of macrolides over fluoroquinolones [36, 37].

Regarding patients with risk factors for $P$. aeruginosa and MRSA; three main scenarios could be possible. First, if the patient carried some of these microorganisms, the AG recommended to cover these micro-organisms regardless of the CAP severity. Second, if none of these micro-organisms were previously isolated but the CAP is severe, the plan of action should be obtaining cultures, starting empiric treatment with coverage for these microorganisms and deescalating if cultures are negative and the patient is stable (both conditions should be present). Finally, if none of the microorganisms were isolated but the CAP is not severe, cultures should be obtained and the coverage should be withheld until their results.

Regarding the duration of antibiotic therapy, both guidelines are relatively similar. The EG suggest at most 8 days in responder patients and the AG emphasize that shorter courses are as effective as longer courses. Thus, they recommend that the duration of antibiotics should be guided by the clinical response and a minimum of 5 days is necessary. Longer courses of antibiotics are recommended for pneumonia complicated by meningitis, bacteremia by $S$. aureus, endocarditis and other deep-seat infections or uncommon pathogens (eg. Burkholderia pseudomallei, Mycobacterium tuberculosis or endemic fungi).

Other antibiotics. AG guidelines mentioned two newest antibiotics, omadacycline and lefamulin. The former is a new aminomethylcycline antibiotic, derived from the tetracycline class that overcomes the efflux and ribosomal protection mechanisms of tetracycline resistance [38]. It has a high and sustained concentration in human pulmonary tissue and in vitro has activity against $S$. pneumoniae, Haemophilus influenzae, S. aureus, and atypical pathogens (L. pneumophila, M. pneumoniae, and C. pneumoniae)[39, 40]. The latter, is a new type of antibiotic denominated pleuromutilin. Lefamulin acts by binding to the peptidyl transferase center on the bacterial ribosome interfering with the protein production resulting in the inhibition of bac- 
terial proteins and the cessation of bacterial growth. Lefamulin was approved for intravenous and oral use in humans and it is active against the most common CAP-causing pathogens, including some strains resistant to other antimicrobial classes [4143]. Despite the fact that well-designed RCTs $[41,44,45]$ have demonstrated that these two new antibiotics are non-inferior to moxifloxacin, the AG suggested that more evidence is required to recommend them. Additionally, it is worth mentioning that ceftobiprole, the other fifth generation cephalosporine, was not considered in any of the two guidelines despite having almost the same coverage as ceftaroline, is active against $P$. aeruginosa and one RCT, that included severe patients with CAP, demonstrated its efficacy [46].

Antiviral therapy. The interest in virus as a pathogen in CAP has increased since its high prevalence was demonstrated [1]. The cornerstone of the treatment are anti-viral drugs, mainly neuraminidase inhibitors such as oseltamivir or zanamivir. The AG recommends antiviral treatment for all patients with positive influenza test, independent of illness duration and the severity of the disease (outpatients and inpatients). On the contrary, the EG suggests treating only if the duration of symptoms is less than 48 hours.

According to the $A G$, antiviral therapy should be always associated to standard antibacterial treatment (see below). However, the latter treatment could be discontinued after 48 or 72 hours if no evidence of bacterial infection was confirmed (negative cultures and antigens), PCT is low, and the patient is clinically stable.

\section{ADJUVANT THERAPIES}

Currently, it is well accepted that local and systemic host response is absolutely necessary for the CAP resolution. However, if this mechanism is dysregulated, it can lead severe entities (e.g. multiorgan dysfunction and respiratory failure) able to cause the patient death despite the micro-organism had been eradicated.

Steroids is one of the oldest interventions prescribed with the aim reduce the host response. their prescription with the aim to improve the CAP outcome is not so clear and national societies have adopted opposite positions (e.g. British guidelines state that "... steroids are not recommended in the routine treatment of high severity CAP" while South African guidelines recommend "use of systemic corticosteroids should be considered in patients with severe CAP requiring intensive care unit (ICU) admission")[47, 48].

Resolving this contradiction is not only merely an academic exercise as this medication is associated with severe side effects such as hyperglycemia, hyperleukocytosis, increased rates of bleeding, secondary infection, etc. Although results from RCTs are inconclusive, or just improve soft outcomes [49-52], a recent meta-analysis reported that steroid could significantly decrease the mortality [53]. Both guidelines agree on not routinely recommending steroids in patients with CAP without septic shock or other disease that require steroids.
Macrolides have, in addition to their antimicrobial effect, several immunomodulatory properties (e.g. decrease the levels of proinflammatory cytokines such as IL-6 and increase levels of anti-inflammatory cytokines such as IL-10 as well as affect the structural cells of the respiratory tract that may modifying the migration of inflammatory cells to the lungs). Both guidelines usually recommend this type of antibiotics in association to a beta-lactam (vide supra)

Other interventions proposed for host response immunomodulation but not mentioned in $E G$ or $A G$ are:

- Vitamin C. Low concentrations of ascorbic acid in patients with sepsis are inversely correlated with the incidence of multiple organ failure and directly correlated with survival[ $[54$, 55]

- Aspirin. Observational studies have shown that the mortality owing to CAP is lower in patients using aspirin and that the combination of aspirin and macrolides improves survival in patients who present with septic shock owing to pneumonia[56].

- Immunoglobulins. The effect of this kind of molecules have been linked to the bacterial opsonization improvement, prevention of nonspecific complement activation, protection against antibiotic-induced endotoxin release, and neutralization of endotoxin and superantigens. Although two meta-analyses have shown a benefit of immunoglobulin use in patients with severe sepsis and septic shock[57, 58], a phase II study failed to demonstrate a significant difference in ventilator free day and mortality between a human polyclonal antibody preparation (trimodulin) and placebo groups. However, the post hoc analyses supported improved outcome regarding mortality with trimodulin in subsets of patients with elevated CRP, reduced IgM, or both[59].

\section{CONCLUSIONS}

Despite $E G$ and $A G$ were published with almost one decade of difference, both have more points in common than differences. In term of antibiotics recommendation, both are nearly similar with the difference that ceftaroline was included in the latter. Probably, in the near future, the availability of current antibiotics and molecular diagnosis test as well as the outbreak of new micro-organism (e.g. SARS-COV2) will determine an update of both guidelines.

\section{CONFLICTS OF INTEREST} terest

The authors declare that they have no conflict of in-

\section{REFERENCES}

1. Jain $S$, Self WH, Wunderink RG, Fakhran $S$, Balk R, Bramley AM, et al. Community-Acquired Pneumonia Requiring Hospitalization among U.S. Adults. New Eng J Med. 2015;373(5):415-27. DOI: 


\subsection{6/NEJMoa 1500245}

2. Wunderink RG, Waterer GW. Clinical practice. Community-acquired pneumonia. New Eng J Med. 2014;370(6):543-51. DOI: 10.1056/ NEJMcp1214869

3. Mandell LA.Community-acquired pneumonia:An overview. Postgrad Med. 2015;127(6):607-15. DOI: 10.1080/00325481.2015.1074030

4. Collaborators GL. Estimates of the global, regional, and national morbidity, mortality, and aetiologies of lower respiratory tract infections in 195 countries: a systematic analysis for the Global Burden of Disease Study 2015. Lancet Infect Dis. 2017;17(11):1133-61. DOI: 10.1016/S1473-3099(17)30396-1

5. Mortality GBD, Causes of Death C. Global, regional, and national life expectancy, all-cause mortality, and cause-specific mortality for 249 causes of death, 1980-2015: a systematic analysis for the Global Burden of Disease Study 2015. Lancet. 2016;388(10053):1459544. DOI: 10.1016/S0140-6736(16)31012-1

6. Ferreira-Coimbra J, Tejada S, Campogiani L, Rello J. Levels of evidence supporting European and American community-acquired pneumonia guidelines. Eur J Clin Microbiol Infect Dis. 2020;39(6):1159-67. DOI: 10.1007/s10096-020-03833-8

7. Phua J, Ngerng WJ, Lim TK. The impact of a delay in intensive care unit admission for community-acquired pneumonia. Eur Resp J. 2010;36(4):826-33. DOI: 10.1183/09031936.00154209

8. Cardinal-Fernandez P, Garcia Gabarrot G, Echeverria P, Zum G, Hurtado J, Rieppi G. Clinical and microbiological aspects of acute community-acquired pneumonia due to Streptococcus pneumoniae. Rev Clin Esp (Barc). 2013;213(2):88-96. DOI: 10.1016/j. rce.2012.09.011

9. Waterer GW. Community-acquired Pneumonia: A Global Perspective. Semin Respir Crit Care Med. 2016;37(6):799-805. DOI: 10.1055/s-0036-1592313

10. Woodhead M, Blasi F, Ewig S, Garau J, Huchon G, leven M, et al. Guidelines for the management of adult lower respiratory tract infections--full version. Clin Microbiol Infect. 2011;17 Suppl 6:E1-59. DOI: 10.1111/j.1469-0691.2011.03672.x

11. Metlay JP, Waterer GW, Long AC, Anzueto A, Brozek J, Crothers K, et al. Diagnosis and Treatment of Adults with Community-acquired Pneumonia. An Official Clinical Practice Guideline of the American Thoracic Society and Infectious Diseases Society of America. Am J Respir Crit Care Med. 2019;200(7):e45-e67. D0I: 10.1164/ rccm.201908-1581ST

12. Kollef MH, Shorr A, Tabak YP, Gupta V, Liu LZ, Johannes RS. Epidemiology and outcomes of health-care-associated pneumonia: results from a large US database of culture-positive pneumonia. Chest. 2005;128(6):3854-62. DOI: 10.1378/chest.128.6.3854

13. Attridge RT, Frei CR, Pugh MJ, Lawson KA, Ryan L, Anzueto A, et al. Health care-associated pneumonia in the intensive care unit: Guideline-concordant antibiotics and outcomes. J Crit Care. 2016;36:265-71. DOI: 10.1016/j.jcrc.2016.08.004

14. Ewig S, Welte T. Adding fuel to the flames? It is time to leave HCAP. Respir Med. 2012;106(9):1309-10. DOI: 10.1016/j.rmed.2012.07.002

15. Boulware DR, Daley CL, Merrifield C, Hopewell PC, Janoff EN. Rapid diagnosis of pneumococcal pneumonia among HIV-infected adults with urine antigen detection. J Infect. 2007;55(4):300-9. DOI: 10.1016/j.jinf.2007.06.014

16. Sinclair $A, X i e X$, Teltscher $M$, Dendukuri N. Systematic review and meta-analysis of a urine-based pneumococcal antigen test for diagnosis of community-acquired pneumonia caused by Streptococcus pneumoniae. J Clin Microbiol. 2013;51(7):2303-10. DOI: 10.1128/JCM.00137-13

17. Huijts SM, Pride MW, Vos JM, Jansen KU, Webber C, Gruber W, et al. Diagnostic accuracy of a serotype-specific antigen test in community-acquired pneumonia. Eur Respir J. 2013;42(5):1283-90. D0I: 10.1183/09031936.00137412

18. Ruf B, Schurmann D, Horbach I, Fehrenbach FJ, Pohle HD. Prevalence and diagnosis of Legionella pneumonia: a 3-year prospective study with emphasis on application of urinary antigen detection. J Infect Dis. 1990;162(6):1341-8. DOI: 10.1093/infdis/162.6.1341

19. Shimada T, Noguchi Y, Jackson JL, Miyashita J, Hayashino Y, Kamiya $T$, et al. Systematic review and metaanalysis: urinary antigen tests for Legionellosis. Chest. 2009;136(6):1576-85. D0I: 10.1378/ chest.08-2602

20. Chartrand $C$, Leeflang MM, Minion J, Brewer T, Pai M. Accuracy of rapid influenza diagnostic tests: a meta-analysis. Ann Intern Med. 2012;156(7):500-11. DOI: 10.7326/0003-4819-156-7-20120403000403

21. Merckx J, Wali R, Schiller I, Caya C, Gore GC, Chartrand C, et al. Diagnostic Accuracy of Novel and Traditional Rapid Tests for Influenza Infection Compared With Reverse Transcriptase Polymerase Chain Reaction: A Systematic Review and Meta-analysis. Ann Intern Med. 2017;167(6):394-409. D0I: 10.7326/M17-0848

22. Renaud B, Santin A, Coma E, Camus N, Van Pelt D, Hayon J, et al. Association between timing of intensive care unit admission and outcomes for emergency department patients with community-acquired pneumonia. Crit Care Med. 2009;37(11):2867-74. DOI: 10.1097/CCM.0b013e3181b02dbb

23. Restrepo MI, Mortensen EM, Rello J, Brody J, Anzueto A. Late admission to the ICU in patients with community-acquired pneumonia is associated with higher mortality. Chest. 2010;137(3):552-7. DOI: 10.1378/chest.09-1547

24. Labarere J, Stone RA, Scott Obrosky D, Yealy DM, Meehan TP, Auble $\mathrm{TE}_{\mathrm{g}}$ et al. Factors associated with the hospitalization of lowrisk patients with community-acquired pneumonia in a cluster-randomized trial. J Gen Intern Med. 2006;21(7):745-52. D0I: 10.1111/j.1525-1497.2006.00510.x

25. Marrie TJ, Huang JQ. Low-risk patients admitted with community-acquired pneumonia. Am. J Med. 2005;118(12):1357-63. DOI: 10.1016/j.amjmed.2005.06.035

26. Mandell LA, Wunderink RG, Anzueto A, Bartlett JG, Campbell GD, Dean NC, et al. Infectious Diseases Society of America/American Thoracic Society consensus guidelines on the management of community-acquired pneumonia in adults. Clin Infect Dis. 2007;44 Suppl 2:S27-72. DOI: 10.1086/511159

27. Charles PG, Wolfe R, Whitby M, Fine MJ, Fuller AJ, Stirling $R$, et al. SMART-COP: a tool for predicting the need for intensive respiratory or vasopressor support in community-acquired pneumonia. Clin 
Infect Dis. 2008;47(3):375-84. DOI: 10.1086/589754

28. Espana PP, Capelastegui A, Gorordo I, Esteban C, Oribe M, Ortega M, et al. Development and validation of a clinical prediction rule for severe community-acquired pneumonia. Am J Respir Crit Care Med. 2006;174(11):1249-56. DOI: 10.1164/rccm.200602-1770C

29. (HICPAC) CfDCaPHICPAC. Antibiotics stewardship statements for antibiotics guidelines- recommendations of the Healthcare Infections Control Practices Advisory Committee 2017 [Available from: https://www.cdc.gov/hicpac/pdf/antibiotic-stewardship-statement.pdf (accessed May 17,2020).

30. Huttner B, Cappello B, Cooke G, Gandra S, Harbarth S, Imi M, et al. 2019 Community-acquired Pneumonia Treatment Guidelines: There Is a Need for a Change toward More Parsimonious Antibiotic Use. Am J Respir Crit Care Med. 2020;201(10):1315-6. DOI: 10.1164/rccm.201911-2226LE

31. Spellberg B, Talbot GH, Brass EP, Bradley JS, Boucher HW, Gilbert $D N$, et al. Position paper: recommended design features of future clinical trials of antibacterial agents for community-acquired pneumonia. Clin Infect Dis. 2008;47 Suppl 3:S249-65. PMC2827629

32. Kiang TK, Wilby KJ, Ensom MH. A critical review on the clinical pharmacokinetics, pharmacodynamics, and clinical trials of ceftaroline. Clin Pharmacokinet. 2015;54(9):915-31. DOI: 10.1007/ s40262-015-0281-3

33. File TM, Jr., Low DE, Eckburg PB, Talbot GH, Friedland HD, Lee J, et al. FOCUS 1: a randomized, double-blinded, multicentre, Phase III trial of the efficacy and safety of ceftaroline fosamil versus ceftriaxone in community-acquired pneumonia. J Antimicrob Chemother. 2011;66 Suppl 3:iii19-32. DOI: 10.1093/jac/dkr096

34. Low DE, File TM, Jr., Eckburg PB, Talbot GH, David Friedland H, Lee J, et al. FOCUS 2: a randomized, double-blinded, multicentre, Phase III trial of the efficacy and safety of ceftaroline fosamil versus ceftriaxone in community-acquired pneumonia. J Antimicrob Chemother. 2011;66 Suppl 3:iii33-44. DOI: 10.1093/jac/dkr097

35. Zhong NS, Sun T, Zhuo C, D'Souza G, Lee SH, Lan NH, et al. Ceftaroline fosamil versus ceftriaxone for the treatment of Asian patients with community-acquired pneumonia: a randomised, controlled, double-blind, phase 3, non-inferiority with nested superiority trial. Lancet Infect Dis. 2015;15(2):161-71. DOI: 10.1016/S14733099(14)71018-7

36. Sligl WI, Asadi L, Eurich DT, Tjosvold L, Marrie TJ, Majumdar SR. Macrolides and mortality in critically ill patients with community-acquired pneumonia: a systematic review and meta-analysis. Crit Care Med. 2014;42(2):420-32. DOI: 10.1097/CCM.0b013e3182a66b9b

37. Vardakas KZ, Trigkidis KK, Falagas ME. Fluoroquinolones or macrolides in combination with beta-lactams in adult patients hospitalized with community acquired pneumonia: a systematic review and meta-analysis. Clin Microbiol Infect. 2017;23(4):234-41. D0I: 10.1016/j.cmi.2016.12.002

38. Honeyman $L$, Ismail M, Nelson ML, Bhatia B, Bowser TE, Chen J, et al. Structure-activity relationship of the aminomethylcyclines and the discovery of omadacycline. Antimicrob Agents Chemother. 2015;59(11):7044-53. DOI: 10.1128/AAC.01536-15
39. Tanaka SK, Steenbergen J, Villano S. Discovery, pharmacology, and clinical profile of omadacycline, a novel aminomethylcycline antibiotic. Bioorg Med Chem. 2016;24(24):6409-19. DOI: 10.1016/j. bmc.2016.07.029

40. Pfaller MA, Rhomberg PR, Huband MD, Flamm RK. Activity of omadacycline tested against Streptococcus pneumoniae from a global surveillance program (2014). Diagn Microbiol Infect Dis. 2018;90(2):143-7. D0I: 10.1016/j.diagmicrobio.2017.10.010

41. Alexander E, Goldberg L, Das AF, Moran GJ, Sandrock C, Gasink LB, et al. Oral Lefamulin vs Moxifloxacin for Early Clinical Response Among Adults With Community-Acquired Bacterial Pneumonia: The LEAP 2 Randomized Clinical Trial. Jama. 2019. DOI: 10.1001/ jama.2019.15468

42. Paukner S, Sader HS, Ivezic-Schoenfeld Z, Jones RN. Antimicrobial activity of the pleuromutilin antibiotic BC-3781 against bacterial pathogens isolated in the SENTRY antimicrobial surveillance program in 2010. Antimicrob Agents Chemother. 2013;57(9):4489-95. DOI: 10.1128/AAC.00358-13

43. Rodvold KA. Introduction: lefamulin and pharmacokinetic/pharmacodynamic rationale to support the dose selection of lefamulin. J Antimicrob Chemother. 2019;74(Supplement_3):iii2-iii4. DOI: 10.1093/jac/dkz084

44. File TM, Jr., Goldberg L, Das A, Sweeney C, Saviski J, Gelone SP, et al. Efficacy and Safety of IV-to-Oral Lefamulin, a Pleuromutilin Antibiotic, for Treatment of Community-Acquired Bacterial Pneumonia: The Phase 3 LEAP 1 Trial. Clin Infect Dis. 2019; 69(11):1856-1867. DOI: 10.1093/cid/ciz090

45. Stets R, Popescu M, Gonong JR, Mitha I, Nseir W, Madej A, et al. Omadacycline for Community-Acquired Bacterial Pneumonia. New Eng J Med. 2019;380(6):517-27. DOI: 10.1056/NEJMoa1800201

46. Nicholson SC, Welte T, File TM, Jr., Strauss RS, Michiels B, Kaul P, et al. A randomised, double-blind trial comparing ceftobiprole medocaril with ceftriaxone with or without linezolid for the treatment of patients with community-acquired pneumonia requiring hospitalisation. Int J Antimicrob Agents. 2012;39(3):240-6. DOI: 10.1016/j. ijantimicag.2011.11.005

47. Lim WS, Baudouin SV, George RC, Hill AT, Jamieson C, Le Jeune I, et al. BTS guidelines for the management of community acquired pneumonia in adults: update 2009. Thorax. 2009;64 Suppl 3:iii1-55. DOI: 10.1136/thx.2009.121434

48. Boyles TH, Brink A, Calligaro GL, Cohen $C$, Dheda $K$, Maartens $G$, et al. South African guideline for the management of community-acquired pneumonia in adults. J Thorac Dis. 2017;9(6):1469-502. DOI: 10.21037/jtd.2017.05.31

49. Confalonieri $M$, Urbino $R$, Potena $A$, Piattella $M$, Parigi P, Puccio $G$, et al. Hydrocortisone infusion for severe community-acquired pneumonia: a preliminary randomized study. Am J Respir Crit Care Med. 2005;171(3):242-8. DOI: 10.1164/rccm.200406-8080C

50. Siemieniuk RA, Meade MO, Alonso-Coello P, Briel M, Evaniew N, Prasad $M$, et al. Corticosteroid Therapy for Patients Hospitalized With Community-Acquired Pneumonia: A Systematic Review and Meta-analysis. Ann Intern Med. 2015;163(7):519-28. D0I: 10.7326/ M15-0715 
51. Torres A, Sibila O, Ferrer M, Polverino E, Menendez R, Mensa J, et al. Effect of corticosteroids on treatment failure among hospitalized patients with severe community-acquired pneumonia and high inflammatory response: a randomized clinical trial. Jama. 2015;313(7):677-86. DOI: 10.1001/jama.2015.88

52. Blum CA, Nigro N, Briel M, Schuetz P, Ullmer E, Suter-Widmer I, et al. Adjunct prednisone therapy for patients with community-acquired pneumonia: a multicentre, double-blind, randomised, placebo-controlled trial. Lancet. 2015;385(9977):1511-8. DOI: 10.1016/ S0140-6736(14)62447-8

53. Huang J, Guo J, Li H, Huang W, Zhang T. Efficacy and safety of adjunctive corticosteroids therapy for patients with severe community-acquired pneumonia: A systematic review and meta-analysis. Medicine (Baltimore). 2019;98(13):e14636. DOI: 10.1097/ MD.0000000000014636

54. Borrelli E, Roux-Lombard P, Grau GE, Girardin E, Ricou B, Dayer J, et al. Plasma concentrations of cytokines, their soluble receptors, and antioxidant vitamins can predict the development of multiple organ failure in patients at risk. Crit Care Med. 1996;24(3):392-7. DOI: 10.1097/00003246-199603000-00006

55. Fowler AA, 3rd, Syed AA, Knowlson $S$, Sculthorpe $R$, Farthing $D$, DeWilde $C_{\text {, et }}$ al. Phase I safety trial of intravenous ascorbic acid in patients with severe sepsis. J Transl Med. 2014;12:32. DOI: 10.1186/1479-5876-12-32

56. Falcone M, Russo A, Farcomeni A, Pieralli F, Vannucchi V, Vullo V, et al. Septic shock from community-onset pneumonia: is there a role for aspirin plus macrolides combination? Intensive Care Med. 2016;42(2):301-2. DOI: 10.1007/s00134-015-4139-9

57. Alejandria MM, Lansang MA, Dans LF, Mantaring JB, 3rd. Intravenous immunoglobulin for treating sepsis, severe sepsis and septic shock. Cochrane Database Syst Rev. 2013(9):CD001090. D0I: 10.1002/14651858.CD001090.pub2

58. Kreymann $K G$, de Heer G, Nierhaus A, Kluge S. Use of polyclonal immunoglobulins as adjunctive therapy for sepsis or septic shock. Crit Care Med. 2007;35(12):2677-85.

59. Welte $T$, Dellinger RP, Ebelt $H_{1}$ Ferrer M, Opal SM, Singer M, et al. Efficacy and safety of trimodulin, a novel polyclonal antibody preparation, in patients with severe community-acquired pneumonia: a randomized, placebo-controlled, double-blind, multicenter, phase II trial (CIGMA study). Intensive Care Med. 2018;44(4):438-48. DOI: 10.1007/s00134-018-5143-7 